\title{
Meningkatkan Kemandirian Belajar Siswa Dengan Layanan Bimbingan Klasikal Dengan Teknik STAD (Student Teams Achievement Division)
}

\author{
Farrah Arum Pratiwi ${ }^{1}$, H. Sholih ${ }^{2}$, Raudah Zaimah Dalimunthe ${ }^{3}$ \\ Universitas Sultan Ageng Tirtayasa \\ farraharumptaiwi@gmail.com
}

\begin{abstract}
Abstrak
The research is motivated by the problem of independence learning class VII of State Junior High School 7 Serang City in academic year 2019/2020. The purpose of the research was to determine the descriptions of student learning independence and the influence of classical guidance with techniques STAD (Student Teams Achievement Division) in increasing student learning independence. The research type used in the study was pre-experimental design with one group pre-post test design, with a population of class VII there were 193 students and a sample of 40 students selected by purposive sampling technique. The data collection method uses a questionnaire of students' learning independence which has been tested the content validity and has 34 items from 44 valid items. The results of the study found that there were very high categories of 3 students with $1 \%$ percentage, a high category of 67 students with $35 \%$ percentage, a midle category of 83 students with $43 \%$ percentage, and a low category of 40 students with $21 \%$ percentage. Data analysis techniques using the Wilcoxon test. The results of the pretest and posttest data analysis of learning independence, obtained $\mathrm{z}$ count $-5,512 \mathrm{~b}<\mathrm{z}$ table 820.00 , then $\mathrm{Ha}$ is accepted and Ho is rejected, it's mean that it can improve independence learning after given a classical guidance service with technique STAD (Student Teams Achievement Division) to students class VII of State Junior High School 7 Serang City.
\end{abstract}

Keywords: classical guidance, Technique STAD, independence learning

\section{PENDAHULUAN}

Layanan bimbingan dan konseling diberikan kepada seluruh individu dari kalangan usia anak, remaja, dewasa, hingga lanjut usia. Konselor perlu memahami karakteristik setiap individu yang menjadi sasaran layanan bimbingan dan konseling. Agar keberhasilan layanan bimbingan dan konseling dapat tercapai secara optimal. Tohirin $(2016,25)$ mendefinisikan bimbingan merupakan bantuan yang diberikan oleh pembimbing kepada individu agar individu yang dibimbing mencapai kemandirian. Sedangkan konseling didefinisikan Tohirin $(2016,30)$ merupakan kontak atau hubungan timbal balik antara dua orang (konselor dan konseli) untuk 
menangani masalah konseli. Dalam buku Geldard (2016) tujuan bimbingan dan konseling adalah membantu setiap siswa membuat pilihan dan menentukan sikap berdasarkan nilai-nilai sosial, kemampuan, minat, dan kesempatan Skinner.

Setiap individu yang mendapatkan layanan bimbingan dan konseling memiliki karakteristik yang berbeda. Upaya konselor dan guru dalam memahami karakteristik individu dapat diklarifikasikan berdasarkan aspek kemandirian belajar siswa. Kegiatan pengembangan siswa SMP, termasuk remaja menjadi pusat kegiatan belajar. Siswa di sekolah dapat terlihat dalam berbagai jenis kegiatan. Kegiatan siswa tidak hanya mendengarkan dan mencatat, tetapi juga memperluas dan memperdalam pengetahuan dan keterampilan untuk meningkatkan sikap, dan juga bisa mengembangkan kebiasaan berfikir dan bekerja secara produktif.

Berdasarkan penelitian sebelumnya yang menjadi rujukan peneliti hasil observasi Sutanto Priyonugroho berjudul "Efektivitas Teknik STAD Dalam Meningkatkan Kemandirian Belajar Siswa SMP Pawyantan Daha 1 Kediri VIII Tahun Pelajaran 2016/2017”. Berpendidikan tinggi, biasanya rendahnya kemandirian belajar terwujud dalam tingkah laku siswa yang mudah menyerah ketika menghadapi tugas yang sulit dan menyontek saat mengerjakan ulangan atau tugas lainnya. Berdasarkan hasil perhitungan $\mathrm{N}=6$ siswa taraf signifikansi (Ha) dari $\mathrm{T}_{\text {tabel }} 0$ dan $\mathrm{T}_{\text {hitung }} 0$ diterima sebesar $5 \%$ yang artinya teknik pemodelan bermanfaat untuk meningkatkan siswa VIII SMP PAWIYATAN DAHA 1 KEDIRI tahun 2016/2017. Kemandirian belajar tahun pelajaran 2016/2017 efektif, dan (Ho) ditolak karena menurutnya teknik STAD dapat secara efektif meningkatkan kemandirian belajar siswa VIII SMP PAWIYATAN DAHA 1 KEDIRI tahun pelajaran 2016/2017. Dengan menghitung $\mathrm{T}_{\text {hitung }} \leq \mathrm{T}_{\text {tabel, }}$, dapat dibuktikan bahwa $\mathrm{T}_{\text {tabel }} \leq \mathrm{T}_{\text {tabel }}$ adalah $0 \leq 0$ dan taraf signifikansi $5 \%$.

Oleh karena itu tujuan bimbingan dan konseling tidak lepas dari suatu bagian yang tidak terpisahkan dari proses pendidikan dan berhubungan erat dengan siswa di lingkungan sekolah. Tugasnya adalah memberikan bimbingan kepada siswa untuk mengembangkan sikap mandiri dengan melakukan pelayanan yang sesuai, seperti melalui klasikal. Layanan bimbingan dan menciptakan motivasi bagi siswa.

Sehingga hasil studi pendahuluan yang dilaksanakan pada tanggal 2 Oktober 2019 dengan wawancara di SMP Negeri 7 Kota Serang, diperoleh informasi bahwa dalam mengikuti mata pelajaran masih ada sebagian siswa yang kurang memiliki kemandirian belajar. Misalnya siswa tidak ingin berusaha mengerjakan soal sendiri terlebih dahulu, siswa juga jarang memanfaatkan buku paket yang ada untuk mencari sumber dalam membantu pemahaman mereka. Ketika guru menjelaskan di depan kelas dan memberikan catatan yang penting, masih ada siswa yang tidak mencatat. Jika diberikan latihan di sekolah maupun pekerjaan rumah mereka tidak bisa mengerjakan tugas tersebut, beberapa siswa hanya menyontek tugas temannya yang bahkan tidak dikerjakan sama sekali, hal ini terlihat dari hasil jawaban yang sama persis dari beberapa siswa, dan ketika ditanya atau dites ulang siswa tersebut tidak dapat menjelaskan jawabannya. Dalam proses belajar terdapat juga beberapa siswa yang mempunyai kemandirian belajar yang baik hal ini dapat dilihat ketika guru menjelaskan dan memberikan catatan siswa memiliki inisiatif untuk mencatat tanpa diperintah atau dianjurkan. Ketika diberi soal siswa berusaha untuk mengerjakannya sendiri dahulu, jika menemui kesulitan barulah siswa akan bertanya atau mendiskusikannya dengan teman, guru atau orang lain.

Berdasarkan fenomena di atas maka diperlukan pemberian pemahaman belajar pada siswa Sekolah Menengah Pertama (SMP), hal ini dikarenakan setiap mengikuti proses pembelajaran di sekolah sudah pasti setiap siswa mengharapkan mendapatkan hasil belajar yang baik, sebab hasil belajar yang baik dapat membantu siswa dalam mencapai tujuannya. Hasil belajar yang baik hanya dicapai melalui proses belajar yang baik pula. Jika proses belajar tidak optimal sangat sulit diharapkan terjadinya hasil belajar yang baik. Guru bimbingan dan konseling atau konselor sekolah diharapkan paham dan jeli dengan keadaan yang terjadi pada siswa sehingga dalam pemberian pelayanan informasi belajar tidak saja pada saat siswa mulai malas dengan proses belajar mengajar. Guru BK atau konselor memiliki tugas, tanggung jawab dan wewenang dalam pelayanan bimbingan dan konseling terhadap siswa terkait dengan belajar siswa yang sesuai dengan kebutuhan, dan kepribadian siswa di sekolah. Hal ini sesuai dengan 
Peraturan Menteri Pendidikan Dan Kebudayaan Republik Indonesia Nomor 111 Tahun 2014 Tentang Bimbingan Dan Konseling Pada Pendidikan Dasar Dan Pendidikan Menengah Pasal 3 Layanan Bimbingan dan Konseling memiliki tujuan membantu Konseli mencapai perkembangan optimal dan kemandirian secara utuh dalam aspek pribadi, belajar, sosial, dan karier. Salah satu cara yang dapat dilakukan oleh guru bimbingan dan konseling yaitu dengan memberikan layanan pemahaman belajar dengan teknik STAD (Student Teams Achievement Division).

Hasil penelitian Wasi Aqnaa Sari yang berjudul "Upaya Meningkatkan Perilaku Belajar Mandiri Melalui Layanan Bimbingan Klasikal", menunjukkan bahwa perilaku kemandirian meningkat setelah diberikan bimbingan klasikal pada siklus pertama, kedua, dan ketiga. Dibandingkan dengan kondisi awal mengalami peningkatan sebesar 8,04\%. Setelah siklus II dibandingkan dengan kondisi setelah siklus I meningkat 5,40\% (13,44\% lebih banyak dari kondisi awal), dan setelah siklus III meningkat 1,08\% (dibandingkan dengan siklus awal). Dibandingkan dengan kondisi terjadi peningkatan 14,52\%), sehingga total 3 siklus meningkat $14,52 \%$. Peningkatan ini membuktikan bahwa perilaku mandiri siswa dapat ditingkatkan melalui layanan bimbingan klasikal.

Melalui teknik STAD (Student Teams Achievement Division) diharapkan siswa dapat mempunyai pandangan menyeluruh tentang pokok masalah, memungkinkan siswa karena menurut teori konstruksivisme dalam proses pembelajaran di sekolah guru tidak bisa memberikan pengetahuan siswa begitu saja, siswa yang harus membangun sendiri pengetahuannya. Misalnya dengan memberikan kesempatan seluas-luasnya kepada siswa untuk menemukan sendiri informasi dan mengaplikasikannya atau dengan pembelajaran yang mengupayakan pembelajaran siswa memiliki kesadaran untuk menggunakan strateginya sendiri dalam belajar. Sehingga teknik STAD (Student Teams Achievement Division) yang sesuai untuk meningkatkan kemandirian belajar terhadap siswa. Selain itu, pembelajaran STAD (Student Teams Achievement Division) menurut Herdian (2015) memiliki beberapa keunggulan yaitu penugasan harus diberikan kepada semua anggota kelompok, terdapat interaksi langsung antara siswa dengan siswa dan antara siswa dengan guru, membimbing siswa untuk mengembangkan keterampilan sosial dan mendorong siswa untuk menghargai pendapat orang lain dapat meningkatkan potensi akademik siswa serta membimbing siswa untuk berani mengemukakan pendapat di kelas.

\section{METODE}

Metode yang digunakan dalam penelitian ini adalah metode penelitian kuantitatif dengan menggunakan teknik penelitian pra-eksperimen. Sugiyono (Rusita, 2018) berpendapat penelitian kuantitatif digunakan untuk mengamati populasi atau sampel, yang mana instrumen penelitian dipakai untuk pengumpulan data, kemudian untuk menguji hipotesis yang telah ditentukan ditempuh dengan cara analisis data yang bersifat statistik. Adapun teknik yang dipakai adalah pra-eksperimen Darmadi (2015:109) mengemukakan bahwa penelitian pra eksperimental merupakan suatu bentuk rancangan penelitian eksperimental, yang memanipulasi variabel bebas untuk mempengaruhi pembentukan variabel terikat, sehingga disebut rancangan pra eksperimental karena rancangan ini bukan merupakan eksperimen nyata. Eksperimen dilakukan dengan maksud untuk melihat akibat dari suatu perlakuan.

Penelitian ini menggunakan pre-test dan post-test one group design. Dalam desain ini terdapat pre test sebelum diberi perlakuan $\left(O_{1}\right)$ dan post test setelah diberi perlakuan $\left(O_{2}\right)$. Dengan demikian hasil perlakuan dapat diketahui lebih akurat karena dapat membandingkan dengan keadaan sebelum dan setelah diberi perlakuan. Dalam hal ini hanya terdapat satu kelompok eksperimen. Desain tersebut dapat digambarkan sebagai berikut: 


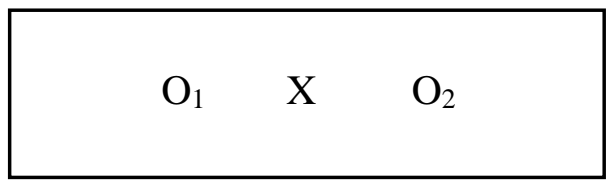

\section{Gambar 1 Kelompok eksperimen}

$\begin{array}{ll}\text { Keterangan: } & \mathrm{O}_{1}=\text { Pretest } \\ & \mathrm{X}=\text { Perlakuan } \\ & \mathrm{O}_{1}=\text { Pre test } \\ & \mathrm{X}=\text { Perlakuan } \\ & \mathrm{O}_{2}=\text { Post test }\end{array}$

Populasi dalam penelitian ini adalah siswa kelas VII A-E di SMP Negeri 7 Kota Srang, yaitu terdiri dari:

\section{Tabel 1 Tabel Populasi Penelitian}

\begin{tabular}{|l|l|l|}
\hline NO & KELAS & JUMLAH SISWA \\
\hline 1 & VII. A & 40 \\
\hline 2 & VII. B & 38 \\
\hline 3 & VII. C & 38 \\
\hline 4 & VII. D & 37 \\
\hline 5 & VII. E & 40 \\
\hline \multicolumn{2}{|l}{ Jumlah } & 193 \\
\hline
\end{tabular}

Adapun subjek penelitian diambil dengan teknik purposive sampling. Dalam hal ini peneliti mengambil sampel siswa yang kurang kemandirian dalam pembelajaran berdasarkan observasi lapangan. Teknik pengambilan data sampel ini biasanya didasarkan oleh pertimbangan tertentu, misalnya keterbatasan waktu, tenaga dan dana sehingga tidak dapat mengambil sampel yang besar dan jauh. Adapun cara dalam penentuan sampel, peneliti menggunakan cara purposive sampling. Hal ini dilakukan dengan cara mengambil subjek bukan didasarkan atas strata, random atau daerah tetapi didasarkan atas adanya tujuan tertentu. Sampel dalam penelitian berjumlah 40 orang.

Sebelum menganalisis data, terlebih dahulu dilakukan uji validitas instrumen untuk mengetahui item-item pernyataan yang valid, dalam penelitian ini dilakukan dengan scale reliability dimana akan ada beberapa butir item yang gugur. Dasar pengambilan keputusan pada uji validitas dengan cara membandingkan nilai $\mathbf{r}_{\text {hitung }}$ dengan $r_{\text {tabel }}$ dan melihat nilai signifikansi (sig). Hasil yang diperoleh dari $\mathrm{n}=39$ maka $r_{\text {tabel }}$ sebesar 0,316 maka item tersebut dinyatakan valid karena, nilai $r_{\text {hitung }}>r_{\text {tabel. }}$. Setelah melakukan uji validitas, angket kemandirian belajar dengan jumlah awal 44 item hanya tersisa 34 item yang valid. Selanjutnya dilakukan uji reliabilitas yang merupakan alat untuk mengukur suatu konsistensi suatu kuesioner yang merupakan indikator dari variabel. Pengukuran reliabilitas yang akan digunakan dalam penelitian ini adalah dengan menggunakan alat analisis SPSS (Statistical Package For Social Science) versi 25 yaitu dengan uji statistic cronbach alpha. Hasil analisis reliabilitas ditemukan skor 0,874 yang dapat diartikan bahwa instrumen berada di kagetori sangat tinggi.

Sedangkan untuk mengetahui keefektifan bimbingan klasikal memakai teknik STAD (Student Teams Achievement Division) untuk meningkatkan kemandirian belajar siswa menggunakan uji wilcoxon. Metode nonparametrik dengan uji Wilcoxon adalah salah satu uji non-parametrik yang mana tidak mensyaratkan suatu data harus berdisitribusi normal untuk membuktikan keefektifan bimbingan klasikal dengan teknik STAD (Student Teams Achievement Division) untuk membantu meningkatkan kemandirian belajar siswa kelas VII SMP Negeri 7 Kota Serang. 


\section{HASIL DAN PEMBAHASAN}

Deskripsi umum hasil skor yang diperoleh dari penyebaran skala kemandirian belajar dengan jumlah populasi yang dipilih, maka berikut adalah kemandirian belajar siswa kelas VII SMP Negeri 7 Kota Serang yang diperoleh dari pengumpulan data terhadap 193 siswa.Hasil keseluruhan dari data di atas, maka dapat diketahui bahwa ada 3 siswa di kategorikan sangat tinggi terhitung 1\%, 67 siswa di kategori tinggi terhitung 35\%, 83 siswa di kategori sedang terhitung $43 \%$, dan 40 siswa di kategori rendah terhitung $21 \%$. Jika menggambar di grafik, maka dapat dilihat sebagai berikut ini:

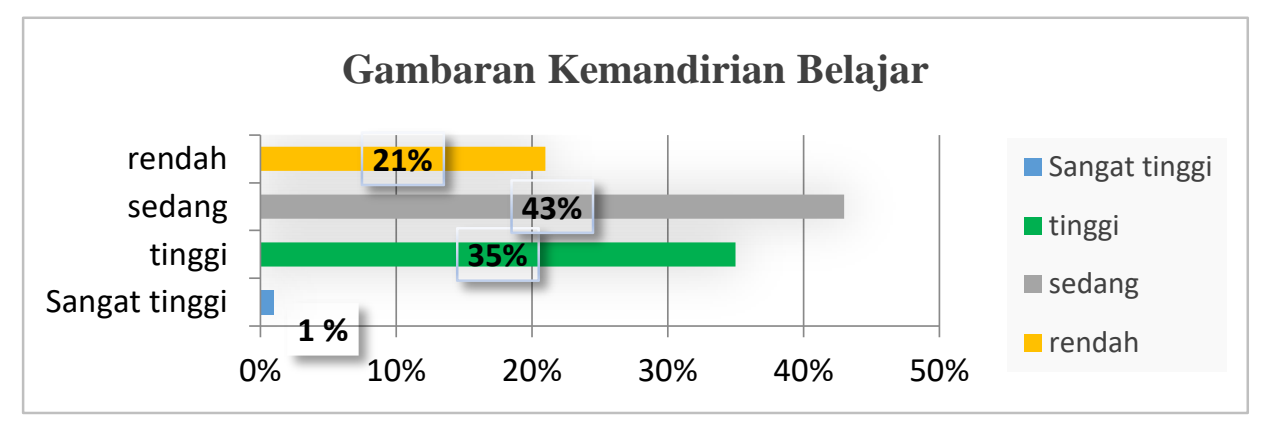

Gambar 2 Grafik Kemampuan Kemandirian Belajar Siswa

Seperti yang terlihat pada gambar di atas, siswa SMP Negeri 7 Kota Serang memiliki kemandirian belajar yang tinggi pada tahun pelajaran 2019/2020. Dari kategori sedang terlihat bahwa kecepatan belajar mereka paling tinggi yaitu $43 \%$.

Penelitian ini menggunakan penelitian eksperimen dengan menggunakan teknik STAD (Student Teams Achievement Division) untuk meningkatkan kemandirian belajar siswa. Pada penelitian ini peneliti menguji data dengan uji wilcoxon. Pengujian prasyaratan analisis ini menggunakan komputer SPPS versi 25. Berikut hasil dari pengujian tersebut:

Tabel 2 Uji Wilcoxon Signed Ranks Test Ranks

\begin{tabular}{|l|l|l|l|}
\hline & $\mathrm{N}$ & $\begin{array}{l}\text { Mean } \\
\text { Rank }\end{array}$ & Sum of Ranks \\
\hline $\begin{array}{l}\text { Posttest - } \\
\text { Pretest }\end{array}$ & $0^{\mathrm{a}}$ & .00 & .00 \\
\hline $\begin{array}{l}\text { Negative } \\
\text { Ranks }\end{array}$ & $40^{\mathrm{b}}$ & 20.50 & 820.00 \\
\hline Ties & $0^{\mathrm{c}}$ & & \\
\hline Total & 40 & & \\
\hline
\end{tabular}

Sehingga hasil data tersebut dapat diketahui bahwa negative ranks atau selisih negative hasil belajar mandiri pre-test dan post-test adalah 0, keduanya adalah N, Mean Rank maupun Sum Rank. Nilai 0 berarti tidak ada penurunan Sehingga hasil data tersebut dapat diketahui bahwa negative ranks atau selisih negative hasil belajar mandiri pre-test dan post-test adalah 0 , keduanya adalah N, Mean Rank maupun Sum Rank. Nilai 0 berarti tidak ada penurunan (pengurangan) nilai dari sebelum tes ke setelah tes.

Nilai positif atau selisih antara hasil belajar mandiri pre-test dan post-test (positif) meliputi 40 data positif (N) data positif, yang menunjukkan bahwa kemandirian belajar 40 siswa dari pre-test hingga post-test telah meningkat. Mean rank atau rata-rata peningkatan adalah 20.50, dan jumlah sum of rank tersebut adalah 820.00. Ties adalah kemiripan antara pre-test dan post-test. Nilai ties disini adalah 0 , sehingga dapat dikatakan tidak ada nilai yang sama antara pre-test dan post-test. 
Tabel 3 Hasil Uji Test Statisticsa

\begin{tabular}{|l|l|}
\hline & $\begin{array}{c}\text { Posttest } \\
- \\
\text { Pretest }\end{array}$ \\
\hline $\mathrm{Z}$ & $-5.512^{\mathrm{b}}$ \\
\hline Asymp. Sig. (2-tailed) & .000 \\
\hline
\end{tabular}

Dari hasil data tersebut menunjukan bahwa hasil test statistics, diketahui Asymp.Sig (2tailed) bernilai 0,000 karena nilai 0,000 lebih kecil dari $<0,05$ yang berarti $\mathrm{H}_{\mathrm{o}}$ ditolak dan $\mathrm{H}_{\mathrm{a}}$ diterima maka dapat disimpulkan bahwa "Hipotesis diterima" artinya ada perbedaan antara kemandirian belajar untuk Pre Test dan Post Test sehingga dapat disimpulkan pula bahwa "ada pengaruh penggunaan Bimbingan Klasikal dengan Teknik STAD (Student Teams Achievement Division) untuk meningkatkan kemandirian belajar siswa SMP Negeri 7 Kota Serang kelas VII. Dari data tersebut diketahui bahwa terjadi peningkatan kemandirian belajar siswa, sebelum diberi Pretest nilai rata-rata 59,47 setelah melaksanakan treatment layanan bimbingan klasikal dengan teknik STAD (Student Teams Achievement Division) nilai rata-rata naik menjadi 113,75 .

Menurut Desmita (2015: 185) kemandirian atau otonom merupakan "kemampuan untuk mengendalikan dan mengatur pikiran, perasaan dan tindakan sendiri secara bebas serta berusaha sendiri untuk mengatasi perasaan-perasaan malu dan keraguan". Dalam berkembangnya kemandirian individu dapat ditentukan ketika individu mampu atau tidak dalam menyelesaikan suatu permasalahan yang dihadapi. Sejalan dengan pendapat di atas, Desmita (2015: 185-186) mengemukakan orang yang mandiri memiliki ciri-ciri sebagai berikut: (1) memiliki hasrat bersaing untuk maju demi kebaikan dirinya sendiri, (2) mampu mengambil keputusan dan inisistif untuk mengatasi masalah yang dihadapi, (3) memiliki kepercayaan diri dalam melaksanakan tugas-tugasnya, (4) bertanggung jawab atas apa yang dilakukannya.

Berdasarkan penelitian yang dilakukan oleh peneliti terhadap 193 orang siswa SMP

Negeri 7 Kota Serang terdapat 21\% siswa di SMP Negeri 7 Kota Serang terdapat 40 siswa dengan kemandirian belajar rendah, $43 \%$ siswa dengan kemandirian belajar sedang terdapat 83 siswa, 35\% sebanyak 67 siswa kategori kemandirian belajar tinggi, hingga 1\% memiliki tingkat kemandirian yang sangat tinggi dalam belajar terdapat 3 siswa. Dari hasil penelitian dapat diambil kesimpulan bahwa kemandirian belajar siswa kelas VII SMPN 7 Kota Serang rata-rata berada dalam kategori sedang, namun dari hasil pretest juga ditemukan terdapat siswa yang memiliki kemandirian belajar yang rendah. Hasil penelitian juga menunjukan hasil perhitungan dari aspek-aspek kemandirian belajar yang menunjukkan bahwa setiap aspek berada dalam kategori sedang.

Selanjutnya, menindaklanjuti hasil pretest dilakukan treatment kepada 40 orang siswa yang masuk kategori rendah. Treatment menggunkan teknik STAD (Student Teams Achievement Division) dilakukan sebanyak 5 kali, treatment dilakukan dengan berdasarkan kepada aspek-aspek yang mempengaruhi kemandirian belajar. Pada saat treatment, siswa sangat antusias mengikutinya, terutama pada saat penyampaian materi tentang belajar kelompok yang efektif dan ketagihan belajar. Siswa mengatakan bahwa mereka kekurangan motivasi untuk dirinya bangkit dalam belajar dan mengatur jadwal belajar serta membuat catatan kecil tujuan atau target belajar. Setelah treatment dilakukan diketahui bahwa terjadi peningkatan kemampuan kemandirian belajar siswa, sebelum diberi Pretest nilai rata-rata 59,47 setelah melaksanakan treatment layanan dasar dengan teknik STAD (Student Teams Achievement Division) nilai rata-rata naik menjadi 113,75.

Gagasan utama STAD (Student Teams Achievement Division) merupakan memacu siswa agar saling mendorong dan membantu satu sama lain untuk menyelesaikan masalah yang diberikan oleh guru. Teknik STAD (Student Teams Achievement Division) didesain untuk meningkatkan rasa tanggung jawab siswa terhadap pembelajarannya sendiri dan juga 
pembelajaran orang lain. Siswa tidak hanya mempelajari materi yang diberikan, tetapi mereka harus siap memberikan dan mengajarkan materi tersebut pada anggota kelompoknya yang lain. Dengan demikian, "siswa saling tergantung satu dengan yang lain dan harus bekerja sama secara kooperatif untuk mempelajari materi yang ditugaskan (Lie, A. 2015: 27)."

Sedangkan Layanan bimbingan klasikal dalam meningkatkan kemandirian belajar siswa yaitu untuk merencanakan kegiatan penyelesaian studi, membimbing perkembangan karir serta kehidupannya dimasa yang akan datang, mengembangkan potensi dan kekuatan yang dimiliki siswa secara optimal, membantu siswa menyesuaikan diri dengan lingkungannya, serta membantu siswa menyelesaikan permasalahnnya dalam belajar untuk mencapai kesuksesan dalam mencapai tujuan belajar. Prinsip-prinsip layanan bimbingan klasikal, yaitu: (1) layanan bimbingan klasikal, diperuntukkan bagi semua siswa atau konseli. Meski demikian materi yang diberikan tetap didasarkan atas kebutuhan mereka. Tema atau topik atau materi yang diberikan didasarkan atas kebutuhan konseli yang diungkap dari hasil need assessment, (2) bimbingan dan konseling sebagai proses individuasi. Meskipun menggunakan pendekatan bimbingan klasikal di mana aktivitasnya dikelola dalam suatu kelompok besar, setiap konseli tetap diberlakukan sebagai individu yang bersifat unik (berbeda satu sama lainnya). Bimbingan ditujukan pada perkembangan setiap individu untuk menjadi dirinya sendiri secara utuh (Prayitno, 134:2017).

Berdasarkan hasil analisis mengenai kemandirian belajar siswa sebelum diberikan teknik STAD (Student Teams Achievement Divison) dengan layanan bimbingan klasikal termasuk dalam kategori rendah. Namun setelah mendapatkan perlakuan berupa teknik STAD (Student Teams Achievement Divison) dengan layanan bimbingan klasikal mengalami peningkatan sehingga termasuk dalam kategori tinggi dan sangat tinggi. Berdasarkan hasil analiasis menunjukkan bahwa ada perbedaan kemandirian belajar siswa sebelum dan setelah diberikan treatmen. Kemandirian belajar siswa setelah diberikan perlakuan (treatment) menjadi lebih tinggi dibandingkan sebelum diberikan perlakuan (treatment). Dengan kata lain, setelah diberikan teknik STAD (Student Teams Achievement Divison) dengan layanan bimbingan klasikal.

Sesuai dengan penelitian Adiputra (2015:45) hal ini diperoleh skor sebelum dan sesudah diberikannya perlakuan. Sebanyak 24 siswa menjadi sampel terdiri dari 12 siswa sebagai kelompok eksperimen dan 12 siswa sebagai kelompok kontrol. Kelompok eksperimen yang diberikan perlakuan mengalami perubahan yang signifikan sebesar 0,001 atau probabilitas di bawah alpha 0,05 .

Berdasarkan uraian tersebut dapat dikatakan bahwa pemberian teknik STAD (Student Teams Achievement Divison) dapat meningkatkan kemandirian belajar siswa kelas VII SMP Negeri 7 Kota Serang. Selama proses penelitian peneliti melakukan pengolahan semaksimal mungkin sesuai prosedur yang dijadwalkan agar penelitian dapat berjalan dengan lancar, namun peneliti masih memiliki batasan. Batasan yang terjadi antara lain hasil observasi awal menunjukkan bahwa kemandirian belajar dan pengaruhnya tergolong rendah, namun hasil penelitian menunjukkan bahwa kemandirian belajar tinggi. Selanjutnya, peneliti berusaha menyusun instrumen sebanyak-banyaknya, namun masih terdapat kekurangan diantaranya beberapa item pernyataan yang gugur saat pengujian instrumen, sehingga tidak dapat digunakan untuk mengukur variabel yang diteliti.

\section{SIMPULAN}

Berdasarkan pembahasan mengenai efektivitas bimbingan klasikal dengan Teknik STAD (Student Teams Achievement Division) untuk meningkatkan kemandirian belajar siswa kelas VII di SMP Negeri 7 Kota Serang, maka dapat disimpulkan bahwa bimbingan klasikal dengan Teknik STAD (Student TeamS Achievement Division) terbukti efektif untuk meningkatkan kemandirian belajar siswa. Pelaksanaan intervensi pada umumnya sudah dilaksanakan sesuai dengan rancangan intervensi yang telah disusun. Setiap sesi memiliki tujuan yang berbeda pada masingmasing intervensi serta berfokus pada enam indikator penelitian. 


\section{DAFTAR PUSTAKA}

Adiputra. (2015). Landasan Formal Bimbingan dan Konseling di Indonesia. Ciptapustaka Media Perintis: Bandung.

Darmadi, H. (2015). Psikologi Perkembangan. Bandung: Remaja Rosdakarya.

Desmita, (2015). Psikologi Perkembangan Peserta Didik Panduan Bagi Orang Tua dan Guru dalam Memahami Psikologi Anak Usia SD, SMP, dan SMA. Bandung: Remaja Rosdakarya

Geldard, K. (2016). Konseling Remaja. Yogyakarta: Pustaka Belajar.

Herdian. (2015). Model Pembelajaran STAD (Student Teams Achievement Division). (Online), (http://herdy07.wordpress.com/2015/06/22/model-pembelajaran-stad-student-teamsachievement-division/), diakses tanggal 27 Februari 2019.

Kementerian Pendidikan dan Kebudayaan. (2014). Peraturan Menteri Pendidikan Dan Kebudayaan Republik Indonesia Nomor 111 Tahun 2014 Tentang Bimbingan Dan Konseling Pada Pendidikan Dasar Dan Pendidikan Menengah. Jakarta: Kemendikbud.

Lie, A. (2015). Jurnal Teknologi Pendidikan dan Pembelajaran. Pengaruh Model Pembelajaran Student Teams Achievement Divisions (STAD) dan Konvensional terhadap Prestasi Belajar Siswa Ditinjau dari Minat Belajar pada Mata Pelajaran IPS Kelas VIII MTS Negeri di Kabupaten Kudus. 27, (2), 91-100.

Prayitno. (2017). Konseling Profesional yang Berhasil. Rajawali Press: Jakarta.

Rusita. (2018). Menjadi Guru Profesional. Bandung: Remaja Rosdakarya.

Sugiyono. (2015). Metode Penelitian Kombinasi (Mix Methods). Bandung: CV Alfabeta.

Tohirin. (2016). Bimbingan dan Konseling di Sekolah (Berbasis Integrasi). Jakarta: Rajagrafindo Persada 